\title{
PENGARUH PARITAS DAYA BELI, PARITAS SUKU BUNGA TERHADAP NILAI TUKAR RUPIAH DAN DOLLAR AMERIKA SERIKAT
}

\author{
Robiatul Adhawiyah' 1 \\ Maretha Ika Prajawati2 \\ Rieza Firdian ${ }^{3}$ \\ 1,2Fakultas Ekonomi UIN Maulana Malik Ibrahim Malang \\ Email: marethaprajawati@yahoo.co.id \\ 3 Fakultas Ekonomi Syariah STAINU Malang \\ Email: riezafirdian@yahoo.com
}

\begin{abstract}
The exchange rate will react against change of inflation and interest rate, at least there are three theories that explain the relationship between inflation, interest rate, and exchange rate, namely purchasing power parity, interest rate parity, and international fisher effect. The purpose of this study was to determine the influence of purchasing power parity, interest rate parity, and international fisher effect on the Rupiah exchange rate against US Dollar. The populations in this research included inflation time series data, nominal interest rate, real interest rate, and Rupiah exchange rate. The data used in is secondary data form the inflation report, nominal interest rate, real interest rate, and Rupiah exchange rate quarterly. The independent variable used purchasing power parity, interest rate parity, and international fisher effect,the dependent variable used the Rupiah exchange rate against US Dollar. The result of this study indicated that the purchasing power parity, interest rate parity simultaneously had a significant influence on the exchange rate of Rupiah/US Dollar.
\end{abstract}

Keywords: Purchasing Power Parity, Interest Rate Parity, Rupiah Exchange Rate/US Dollar

\section{PENDAHULUAN}

Perdagangan Internasional mengakibatkan terjadinya pertukaran mata uang antar negara yang direfleksikan dalam kurs mata uang. Dalam perdagangan internasional, nilai suatu komoditi diukur dalam mata uang domestik dan mata uang luar negeri yang disebut valuta asing. Harga mata uang suatu negara asing yang dinyatakan dalam mata uang negara lain disebut nilai tukar. Perbandingan nilai antar mata uang disebut dengan kurs (Yuliati dan Prasetyo, 2005:101). 
Indonesia dalam melakukan perdagangan internasional memerlukan devisa (foreign exchange) berupa mata uang kuat (hard currency) yaitu mata uang yang bisa diterima secara luas sebagai bukti pembayaran internasional dan digunakan sebagai alat tukar dalam transaksi internasional (Kuncuro, 2001:18). Adapun mata uang yang tergolong dalam kategori hard currency adalah Dollar Amerika Serikat. Indonesia yang merupakan partner aktivitas perdagangan (ekspor dan impor) dengan Amerika Serikat secara otomatis menilai kegiatan perdagangannya dengan mata uang USD.

Peranan USD menjadi sangat penting sebab aktivitas perdagangan internasional dilakukan oleh Indonesia dengan menggunakan mata uang USD. Jika kurs Rupiah (IDR) terhadap Dollar Amerika (USD) tidak stabil, akan cenderung mengganggu aktivitas perdagangan sebab dapat menimbulkan kerugian ekonomi karena kegiatan perdagangannya dinilai dengan mata uang Dollar Amerika (USD).

Madura (2006:128) menjelaskan bahwa ada beberapa faktor yang dapat mempengaruhi laju perubahan nilai tukar, salah satunya adalah tingkat inflasi. Tingginya angka inflasi mempengaruhi besaran nilai tukar (Madura, 2000:89). Faktor lain yang mempengaruhi nilai tukar mata uang suatu negara adalah perbedaan tingkat bunga antar negara (Hanafi, 2003:110). Perubahan pada suku bunga mempengaruhi investasi pada sekuritas asing, yang akan mempengaruhi penawaran dan permintaan uang sehingga mempengaruhi nilai tukar (Madura, 2006:129). Kurs valas akan bereaksi terhadap perubahan inflasi dan suku bunga, setidaknya ada tiga teori yang menjelaskan hubungan antara inflasi, suku bunga dan valas, yaitu paritas daya beli, paritas suku bunga, dan efek fisher internasional (Kuncoro, 2000:227).

Peneliti tertarik untuk mengetahui keberlakuan teori paritas daya beli (PPP), paritas suku bunga (IRP) yaitu teori yang menerangkan pengaruh selisih inflasi dan selisih suku bunga antar dua negara terhadap nilai tukar pada mata uang Dollar Amerika Serikat terhadap Rupiah Indonesia.

Mata uang asing yang dipilih adalah dollar Amerika Serikat mengingat mata uang ini diakui secara internasional dan paling banyak digunakan dalam transaksi keuangan maupun perdagangan. Tujuan yang ingin dicapai dalam penelitian ini adalah untuk mengetahui pengaruh paritas daya beli yang ditentukan dari rasio inflasi Indonesia dengan inflasi Amerika Serikat pada nilai tukar Rupiah terhadap Dollar Amerika Serikat serta pengaruh parsial paritas suku bunga yang ditentukan dari rasio suku bunga 
nominal Indonesia dengan Amerika Serikat pada nilai tukar Rupiah terhadap Dollar Amerika Serikat.

\section{KAJIAN PUSTAKA \\ Paritas Daya Beli}

Menurut Madura (2000:208), teori paritas daya beli berfokus pada hubungan inflasi dengan nilai tukar, bahwa nilai tukar akan menyesuaikan diri dari waktu ke waktu untuk mencerminkan selisih inflasi antara dua negara, akibatnya daya beli konsumen untuk membeli produk-produk domestic akan sama dengan daya beli mereka untuk membeli produkproduk luar negeri. Artinya, nilai tukar suatu mata uang akan berubah sebagai reaksi terhadap perbedaan inflasi antar dua negara dan daya beli konsumen ketika membeli produk domestic akan sama dengan daya beli pada saat melakukan impor dari negara lain.

Perbedaan antara teori paritas daya beli dengan hukum satu harga terletak pada jumlah komoditas yang diukur, hokum satu harga berlaku hanya pada satu jenis barang/jasa saja, namun paritas daya beli berlaku pada sekeranjang barang dan jasa (basket of goods). Teori paritas daya beli ini pada dasarnya adalah sebuah cara untuk meramalkan kurs keseimbangan jika suatu negara mengalami suatu ketidakseimbangan neraca pembayaran. Teori paritas daya beli adalah teori yang menyatakan bahwa nilai tukar antar mata uang dari dua negara akan berada dalam keseimbangan apabila harga sekelompok barang dan jasa di kedua negara sama.

\section{Paritas Suku Bunga}

Kondisi paritas daya beli berlaku di pasar barang. Kondisi yang sama juga dapat terjadi di pasar sekuritas. Kondisi paritas di pasar sekuritas disebut sebagai paritas suku bunga. Paritas suku bunga menjelaskan bahwa dalam kondisi tidak ada friksi, tingkat pengembalian investasi dari suatu mata uang atau biaya peminjaman dalam suatu mata uang akan sama diberbagai negara (Yuliati dan Prasetyo, 2005:111). Sedangkan menurut Madura (2000:192) paritas suku bunga atau Interest Rate Parity (IRP) merupakan kondisi ekuilibrium dimana selisih suku bunga antara dua valuta diimbangi oleh selisih kurs forward dengan kurs spot.

Asumsi yang melandasi paritas suku bunga adalah bahwa pasar asset merupakan pasar yang efisien. Karena itu paritas ini dapat diterapkan untuk 
investasi dan pinjaman internasional. Logikanya, untuk proyek investasi, investor membandingkan hasil (return) dari pasar domestic dengan hasil dari pasar internasioanl, dimana yang terakhir adalah hasil dari asset luar negeri ditambah premi forward. Bagi proyek pembiayaan, peminjam membandingkan biaya dari pasar domestic dengan pasar luar negeri.

Kondisi paritas suku bunga mengatakan bahwa keuntungan (tingkat bunga) yang dihedge melalui kontrak forward akan sama di negara di dunia. Keuntungan yang dihedge tersebut sering juga disebut sebagai covered interest rate. Jika kondisi paritas suku bunga tidak terpenuhi, abritase bisa dilakukan melalui investasi antarnegara dipasar spot, kemudian secara simultan memasuki kontrak forward untuk menghedge transaksi spot. Dalam kondisi keseimbangan, kesempatan abritase semacam itu tidak bisa dilakukan. Dengan demikian kondisi paritas suku bunga mengkaitkan perbedaan tingkat bunga, serta perbedaan antara pasar forward dengan pasar spot (premi atau diskonto kurs forward) (Hanafi, 2003:214).

\section{Inflasi}

Inflasi adalah suatu proses kenaikan harga-harga yang berlaku dalam suatu perekonomian. Tingkat inflasi (presentasi pertmabahan harga-harga) berbeda dari suatu periode ke periode lainnya, dan berbeda pula dari suatu negara ke negara lain (Sukirno, 2000:15). Sedangkan menurut Boediono (2008:155) inflasi adalah suatu peristiwa moneter yang dapt dijumpai di hampir semua negara di dunia. Mankiw (2006:30) berpendapat bahwa inflasi adalah peningkatan dalam seluruh tingkat harga, sementara Putong (2007:319) menyebutkan bahwa inflasi adalah naiknya harga-harga komoditi secara umum yang disebabkan oleh tidak sinkronnya antara program system pengadaan komoditi (produksi, penentuan harga, percetakan uang dan lain sebagainya) dengan tingkat pendapatan yang dimiliki oleh masyarakat. Inflasi adalah suatu keadaan dimana harga barang dan jasa naik secara keseluruhan, sehingga mengakibatkan nilai mata uang suatu Negara mengalami depresiasi. Sedangkan kebalikan dari inflasi adalah deflasi, yaitu penurunan harga-harga secara umum dari periode sebelumnya (nilai inflasi minus).

\section{Suku Bunga}

Sunariyah (2006:80) mendefinisikan suku bunga sebagai harga dari pinjaman. Suku bunga dinyatakan sebagai persentase uang pokok per unit. Bunga merupakan suatu ukuran harga sumber daya yang digunakan oleh 
debitur yang dibayarkan kepada kreditur. Bunga (interest) adalah sejumlah uang yang harus dibayarkan oleh satu pihak atas penggunaan dana milik pihak lain selama periode tertentu atau harga yang diterima oleh lender karena menyewakan dawa kepada borrower (Joesoef, 2008:41).Suku bunga adalah jumlah bunga yang dibayarkan per unit waktu yang disebut sebagai persentase dari jumlah yang dipinjamkan. Dengan kata lain, orang harus membayar kesempatan untuk meminjam uang. Biaya peminjaman uang diukur dalam dolar per tahun untuk per dollar yang dipinjam adalah suku bunga (Samuelson, 2004:190). Sedangkan menurut Darmawi (2006:181) tingkat suku bunga merupakan harga yang harus dibayar oleh peminjam untuk memperoleh dana dari pemberi pinjaman untuk jangka waktu yang disepakati.

\section{Nilai Tukar atau Kurs}

Nilai tukar (exchange rate) menurut Eiteman, Stonehill dan Moffet (2010:171) adalah harga satu mata uang suatu Negara yang dinyatakan dalam mata uang Negara lain. Nilai tukar merupakan elemen penting karena nilai tukar berpengaruh pada harga barang domestic relative terhadap harga barang luar negeri (Mishkin, 2008:110). Kurs valuta asing adalah harga mata uang suatu Negara dalam unit komoditas (seperti emas dan perak) atau mata uang Negara lain (Yuliati dan Prasetyo,2005:23). Menurut Hady (2010:15) bahwa valuta asing (valas) atau foreign exchange rate (forex) atau foreign currency diartikan sebagai mata uang asing dan alat pembayaran lainnya yang digunakan untuk melakukan atau mebiayai transaksi ekonomi keuangan internasional dan yang mepunyai catatan kurs resmi pada bank sentral.

\section{Hipotesis}

Mengacu pada tinjauan pustaka dan hasil penelitian terdahulu di atas, maka dapat dirumuskan hipotesis dalam penelitian ini adalah:

$\mathrm{H}_{1}$ : Paritas daya beli yang ditentukan dari rasio Inflasi Indonesia dengan inflasi Amerika Serikat berpengaruh pada nilai tukar Rupiah terhadap Dollar Amerika Serikat.

$\mathrm{H}_{2}$ : Paritas suku bunga yang ditentukan dari rasio suku bunga nominal Indonesia dengan Amerika Serikat berpengaruh pada nilai tukar Rupiah terhadap Dollar Amerika Serikat. 


\section{METODE}

Penelitian ini merupakan penelitian kuantitatif dengan pendekatan deskriptif, yaitu penyelesaian suatu permasalahn atas penelitian yang dilakukan dalam bentuk data/angka yang kemudian dianalisa, diklasifikasikan, dan di implementasikan dalam bentuk uraian.

\section{Populasi dan Sampel}

Populasi dalam penelitian ini meliputi seluruh data time series kuartal inflasi, suku bunga nominal, suku bunga riil dan nilai tukar mata uang Rupiah terhadap Dollar Amerika Serikat selama periode 2006.I sampai 2016.IV yaitu sebanyak 44 kuartal. Periode ini dipilih karena teori paritas daya beli, paritas suku bunga, dan efek fisher internasional akan lebih berlaku pada periode jangka panjang. Peneliti mengambil semua populasi sebagai sampel agar dapat menggambarkan secara tepat variabel yang diteliti.

\section{Data dan Jenis Data}

Seluruh data yang digunakan dalam penelitian ini diperoleh dari internet pada periode Januari 2006 hingga Desember 2016 secara kuartalan. Data yang digunakan dalam penelitian ini meliputi: Data kurs nilai tukar yaitu nilai tukar antara nilai tukar Amerika Serikat terhadap Rupiah Indonesia. Data inflasi, suku bunga nominal dan suku bunga riil negara yang diuji, meliputi data inflasi, suku bunga nominal dan suku bunga riil. Definisi operasional dalam penelitian ini agar lebih jelas akan ditampilkan pada tabel berikut:

Tabel 1. Definisi Operasional

\begin{tabular}{|c|c|c|c|}
\hline Variabel & Konsep & Indikator & Skala \\
\hline Nilai Tukar (Y) & $\begin{array}{l}\text { Harga mata uang } \\
\text { suatu negara yang } \\
\text { dinyatakan dalam } \\
\text { mata uang Negara } \\
\text { lain (Eiteman, } \\
\text { Stonehil, dan Moffett, } \\
\text { 2010:171) }\end{array}$ & $\begin{array}{l}\text { Kurs Tengah }= \\
\frac{\text { kurs Jual+Kurs Beli }}{2}\end{array}$ & Rasio \\
\hline
\end{tabular}




\begin{tabular}{|c|c|c|c|}
\hline $\begin{array}{l}\text { Tingkat Inflasi } \\
\left(\mathrm{X}_{1}\right)\end{array}$ & $\begin{array}{l}\text { Kenaikan harga dari } \\
\text { sekelompok barang } \\
\text { pada suatu negara } \\
\text { (Mankiw, 2006:30) }\end{array}$ & $\begin{array}{l}\text { Inflasi } \\
\frac{I H K n-I H K n-1}{I H K n-1} \times \\
100 \% \\
\text { Sumber: Murni } \\
(2006: 41)\end{array}$ & \begin{tabular}{l}
\multicolumn{1}{c}{ Rasio } \\
Rasio Inflasi = \\
$\frac{1+I h}{1+I f}-1$ \\
Sumber: \\
Madura \\
$(2006: 210)$
\end{tabular} \\
\hline $\begin{array}{l}\text { Tingkat bunga } \\
\text { nominal }\left(\mathrm{X}_{2}\right)\end{array}$ & $\begin{array}{lr}\text { Tingkat bunga yang } \\
\text { terdiri dari tingkat } \\
\text { bunga murni, premi } \\
\text { risiko, } & \text { biaya } \\
\text { transaksi } & \text { dalam } \\
\text { pembayaran } & \text { kredit } \\
\text { dan premi inflasi } \\
\text { (Boediono, 2008:86) }\end{array}$ & & $\begin{array}{c}\text { Rasio suku } \\
\text { bunga nominal } \\
\begin{array}{c}\frac{(1+i h]}{(1+i f)}-1 \\
\text { Sumber: } \\
\text { Madura } \\
(2000: 193)\end{array}\end{array}$ \\
\hline
\end{tabular}

\section{HASIL}

\section{Deskripsi Data}

\section{Rasio Inflasi}

Teori paritas daya beli menyatakan bahwa nilai tukar mata uang antar dua negara dipengaruhi oleh rasio inflasi antar dua Negara tersebut. Rasio inflasi antara Indonesia dan Amerika Serikat selama 2006 hingga 2016 cenderung mengalami fluktuasi. Titik tertinggi rasio inflasi kedua negara ini terletak pada kuartal I ditahun 2006 yaitu sebesar 12.78\%. Sementara titik terendah berada pada kuartal IV tahun 2011 yaitu sebesar 0.80\%. Adapun nilai rata-rata variabel rasio inflasi antara Indonesia dan Amerika Serikat sebesar $4.65 \%$.

\section{Rasio Suku Bunga Nominal}

Rasio suku bunga nominal antara Indonesia dan Amerika Serikat selama periode pengamatan yaitu tahun 2006 hingga 2016 berdasarkan tabel 4.6 cenderung mengalami fluktuasi. Titik tertinggi rasio suku bunga nominal antara Indonesia dan Amerika Serikat ini terletak pada kuartal IV tahun 2008 yaitu sebesar 8,86\% sedangkan titik terendah berada pada kuartal III tahun 2007 yaitu sebesar 3,03\%. Adapun nilai rata-rata variabel rasio suku bunga nominal antara Indonesia dan Amerika Serikat adalah 
6,25\%. Rata-rata rasio suku bunga nominal pada tahun 2006 adalah 6.54\% kemudian mengalami penurunan pada tahun 2007 menjadi 3.41\%. Rasio suku bunga nominal meningkat tajam pada tahun 2008 dan 2009 hingga mencapai angka 6.97\% namun kembali menurun ditahun 2010 sampai 2012. Pada tahun 2013 hingga 2015 rasio suku bunga nominal antara Indonesia dengan Amerika Serikat terus mengalami peningkatan mencapai angka $7.38 \%$, sedangkan ditahun berikutnya mengalami penurunan pada angka $5.58 \%$.

\section{Rasio Suku Bunga Riil}

Suku bunga riil merupakan tingkat suku bunga nominal dikurangi dengan laju inflasi yang terjadi dalam periode yang sama. Rasio suku bunga riil antara Indonesia dan Amerika Serikat selama periode pengamatan yaitu tahun 2006 hingga 2016 berdasarkan tabel 4.9 cenderung mengalami fluktuasi. Titik tertinggi rasio suku bunga riil antara Indonesia dan Amerika Serikat ini terletak pada kuartal III tahun 2011 yaitu sebesar 5,98\% sedangkan titik terendah berada pada kuartal III tahun 2006 yaitu sebesar $4,94 \%$. Adapun nilai rata-rata variabel rasio suku bunga riil antara Indonesia dan Amerika Serikat adalah 1,62\%.

\section{Nilai Tukar Rupiah/Dollar}

Nilai tukar merupakan harga mata uang suatu negara yang diukur menggunakan mata uang negara lain. Data nilai tukar yang digunakan dalam penelitian ini adalah data kurs tengah yang diperoleh dari Bank Indonesia selama periode 2006 hingga 2016 antara Rupiah terhadap Dollar Amerika Serikat dengan perhitungan kuartalan. Nilai tukar Rupiah terhadap Dollar Amerika Serikat seperti yang ditunjukkan cenderung mengalami fluktuasi. Rata-rata nilai tukar selama periode pengamatan yaitu selama 44 kuartal sebesar Rp 10.447/Dollar AS dengan titik terendah sebesar Rp 8.569/Dollar AS pada kuartal kedua tahun 2011 dan mencapai titik tertinggi pada kuartal ketiga tahun 2015 yaitu sebesar Rp 14.055/Dollar AS. Rata-rata nilai tukar pada tahun 2006 sebesar Rp 9.141/Dollar AS, kemudian tiga tahun berikutnya yaitu pada tahun 2007, 2008, dan 2009 nilai tukar Rupiah mengalami depresiasi (pelemahan mata uang) hingga mencapai Rp 10.356/Dollar AS. Pada tahun berikutnya yaitu tahun 2010 dan 2011 nilai tukar Rupiah mengalami apresiasi (penguatan mata uang) mencapai angka Rp 8.773/Dollar AS. Namun hal tersebut tidak berlangsung lama karena pada tahun berikutnya yaitu tahun 2012 hingga 2015 nilai tukar Rupiah terus 
melemah hingga Rp 13.458/Dollar AS, kemudian pada tahun 2016 kembali menguat sebesar Rp 13.330/Dollar AS.

\section{PEMBAHASAN}

\section{Pengaruh Paritas Daya Beli Terhadap Nilai Tukar Rupiah/Dollar}

Dari hasil uji analisis dapat disimpulkan bahwa rasio tingkat inflasi Indonesia dengan Amerika Serikat tidak berpengaruh terhadap nilai tukar Rupiah/Dollar pada tahun 2006 sampai 2016 sehingga hipotesis yang berbunyi "rasio inflasi Indonesia dengan Amerika Serikat berpengaruh terhadap nilai tukar Rupiah/Dollar berdasarkan teori paritas daya beli" ditolak. Hal ini menandakan bahwa model paritas daya beli tidak dapat dijadikan acuan utama untuk memprediksi nilai tukar.

Teori paritas daya beli hanya dapat berlaku apabila hasil koefisien rasio inflasi domestik dengan asing signifikan, bukan bernilai nol, dan memiliki arah positif. Berdasarkan hasil perhitungan statistik, dapat disimpulkan bahwa teori paritas daya beli tidak berlaku untuk nilai tukar Rupiah terhadap Dollar Amerika Serikat.

Hasil penelitian ini sejalan dengan penelitian yang dilakukan oleh Dwi Anggraeni (2007) yang mengindikasikan bahwa adanya faktor lain diluar selisih inflasi yang mempengaruhi nilai tukar seperti perbedaan suku bunga, tingkat pendapatan masyarakat, dan control pemerintah. Hasil dari penelitian ini juga diperkuat oleh Afifudin Nurfatoni (2007) yang menyatakan bahwa selisih tingkat inflasi berdasarkan model paritas daya beli tidak berpengaruh terhadap perubahan nilai tukar aktual mata uang Rupiah terhadap Dollar Amerika Serikat. Namun hasil penelitian ini tidak mendukung hasil penelitian Haifa Binti Syech (2005) dan Nisita Kartikaningtyas (2014) yang menunjukkan bahwa teori paritas daya beli terbukti berlaku pada nilai tukar Rupiah/Dollar Amerika Serikat.

Salah satu keterbatasan dalam pengujian paritas daya beli adalah bahwa hasil pengujian akan bervariasi menurut periode dasar yang digunakan . periode dasar yang dipilih harus mencerminkan suatu posisi ekuilibrium karena periode berikutnya akan dievaluasi dalam perbandingannya dengan periode dasar. Akan tetapi, sulit untuk memilih periode dasar. Bahkan salah satu alasan utama penghapusan atau penolakan 
sistem nilai tukar tetap adalah kesulitan dalam mengidentifikasi nilai tukar ekuilibrium (Madura, 2000:218)

Menurut Yuliati dan Prasetyo (2005:109) dua alasan yang mengakibatkan teori PPP tidak berlaku yaitu:

1. Adanya faktor lain yang berpengaruh. Dalam hal ini selain selisih inflasi diantaranya yaitu perbedaan suku bunga, tingkat pendapatan masyarakat, dan control masyarakat.

2. Tidak adanya produk subtitusi. Ide dibelakang teori PPP adalah bahwa segera setelah harga-harga disebuah Negara menjadi relative tinggi, Negara lain akan mengurangi impor dari Negara tersebut dan beralih ke produk-produk domestic. Namun, jika tidak ada barang subtitusi atau pengganti barang tersebut, maka seberapa mahalnya barang impor Negara lain akan tetap melakukan impor kenegara tersebut.

Menurut Madura (2006:128-133) hal-hal yang memungkinkan teori paritas daya beli tidak signifikan dapat terjadi karena adanya faktorfaktor lain yang mempengaruhi nilai tukar seperti:

1. Suku bunga relatif: jika suku bunga dinegara asal lebih tinggi dari Negara asing, mengakibatkan permintaan akan mata uang Negara asal menjadi meningkat sehingga mata uang Negara asal terapresiasi terhadap Negara asing, walaupun inflasi Negara asal lebih tinggi dari Negara asing.

2. Tingkat pendapatan nasional relatif: tinggi rendahnya pendapatan nasional suatu Negara akanj berpengaruh terhadap tinggi rendahnya mata uang Negara tersebut dalam menilai mata uang Negara asing.

3. Kontrol pemerintah: adanya kebijakan pemerintah dalam mengendalikan nilai tukar mata uangnya mengakibatkan tingginya inflasi dinegara tersebut tidak begitu berpengaruh pada nilai tukar mata uangnya dengan negara asing.

Menurut Madura (2000:208), teori paritas daya beli berfokus pada hubungan inflasi dengan nilai tukar, bahwa nilai tukar suatu mata uang akan berubah sebagai reaksi terhadap perbedaan inflasi antar dua negara. Inflasi merupakan permasalahan yang timbul karena beberapa sebab, salah satunya adalah keinginan masyarakat untuk mengkonsumsi secara berlebih. Dalam rangka membatasi keinginan konsumtif manusia, beberapa ayat al-quran telah memberikan peringatan secara tegas seperti: 
"Bermegah-megahan telah melalaikan kamu, sampai kamu masuk ke dalam kubur, janganlah begitu, kelak kamu akan mengetahui (akibat perbuatanmu itu)" (QS. At Takatsur: 1-3).

Bagi umat islam, dalil di atas seharusnya bisa menjadi pegangan dalam bermuamalah yaitu interaksi antar sesama manusia untuk memenuhi kebutuhannya, baik secara perseorangan, berbangsa, bernegara, maupun antar negara. Timbulnya inflasi sebagai masalah perekonomian, tidak terlepas dengan upaya-upaya manusia untuk mendapatkan kemewahan duniawi, sehingga melanggar prinsip-prinsip ekonomi dalam Islam.

\section{Pengaruh Paritas Suku Bunga Terhadap Nilai Tukar Rupiah/Dollar}

Dari hasil uji analisis dapat disimpulkan bahwa rasio tingkat suku bunga nominal antara Indonesia dengan Amerika Serikat tidak berpengaruh terhadap nilai tukar Rupiah/Dollar pada tahun 2006 sampai 2016 sehingga hipotesis yang berbunyi "rasio suku bunga nominal Indonesia dengan Amerika Serikat berpengaruh terhadap nilai tukar Rupiah/Dollar berdasarkan teori paritas suku bunga" ditolak. Hal ini menandakan bahwa model paritas suku bunga tidak dapat dijadikan acuan utama untuk memprediksi nilai tukar.

Hasil penelitian ini tidak mendukung penelitian yang dilakukan oleh Haifa Binti Syech (2005) yang menyatakan bahwa variabel rasio suku bunga memiliki pengaruh yang positif terhadap nilai tukar Rupiah/Dollar Amerika Serikat sehingga teori paritas suku bunga (IRP) terbukti berlaku.

Dalam kenyataan kondisi paritas suku bunga barangkali tidak berlaku sepenuhnya karena ada biaya transaksi, risiko politik seperti pembatasan aliran dana, perlakuan pajak yang berbeda antara investor domestik dengan asing, meskipun demikian, jika transaksi tersebut dilakukan antara pusat keuangan dunia, maka pembatasan ataupun risiko transaksi menjadi semakin kecil, sehingga penyimpangan dari kondisi paritas suku bunga menjadi semakin kecil. Jika kondisi penyimpangan ada, maka kondisi tersebut tidak akan berumur lama karena akan dimanfaatkan dengan cepat oleh abritaser (Hanafi, 2003:216).

Menurut Eun, Resnick dan Sabherwal (2013:142) meskipun IRP cenderung berlaku cukup baik, IRP tidak selalu berlaku secara tepat sepanjang waktu karena dua alasan, yaitu: 
1. Biaya transaksi

Pada kenyataannya, terdapat biaya transaksi. Suku bunga pada saat pelaku abritase melakukan peminjaman akan cenderung lebih tinggi daripada suku bunga pemberian pinjaman, mencerminkan selisih kurs beli-jual. Demikian pula terdapat selisih kurs beli-jual dalam pasar valuta asing. Pelaku abritase harus membeli valuta asing pada kurs jual yang lebih tinggi dan menjualnya pada kurs beli yang lebih rendah.

2. Kontrol terhadap modal

Alasan utama lain untuk penyimpangan dari IRP adalah kontrol terhadap modal yang diberlakukan oleh pemerintah. Untuk berbagai alasan ekonomi makro, pemerintah kadang kala membatasi arus modal masuk dan keluar. Pemerintah mencapai tujuan ini melalui sarana jawboning, pemberlakuan pajak atau bahkan melarang pergerakan modal lintas Negara saat itu. Langkah-langkah control yang diberlakukan oleh pemerintah ini dapat menurunkan proses abritase secara efektif dan akibatnya penyimpangan dari IRP bisa berlangsung lama.

Teori paritas suku bunga (IRP) menyatakan bahwa nilai tukar suatu mata uang ditentukan dari perbedaan tingkat suku bunga antar dua negara. Ada beberapa pendapat yang menganggap bahwa hanya bunga yang berlipat ganda saja yang dilarang, adapun suku bunga yang "wajar" dan tidak mendzalimi itu diperkenankan. Sebagaimana yang telah dijelaskan dalam Al-quran surat Ali Imron ayat 130:

"Hai orang-orang yang beriman, janganlah kamu memakan riba dengan berlipat ganda dan bertakwalah kamu kepada Allah supaya kamu mendapat keberuntungan (QS. Ali Imron:130).

Dari ayat tersebut dapat diketahui bahwa pola lipat ganda termasuk dalam hal riba yang dilarang agama. Yang dimaksud riba disini adalah riba nasi'ah. Riba nasi'ah adalah pembayaran lebih yang disyaratkan oleh orang yang meminjamkan. Menurut sebagian besar ulama bahwa riba nasi'ah itu selamanya haram walaupun tidak berlipat ganda. 


\section{KESIMPULAN}

Berdasarkan hasil penelitian mengenai pengujian pengaruh paritas daya beli (PPP), paritas suku bunga (IRP), dan efek fisher internasional (IFE) pada nilai tukar Rupiah terhadap Dollar Amerika Serikat periode 2006 hingga 2016 dapat diambil kesimpulan sebagai berikut:

Variabel paritas daya beli berdasarkan rasio inflasi antara Indonesia dan Amerika Serikat terbukti tidak berpengaruh terhadap perubahan nilai tukar Rupiah/Dollar Amerika Serikat karena memiliki arah yang negatif, sehingga teori paritas daya beli (PPP) yang menyatakan bahwa nilai tukar akan menyesuaikan diri dari waktu ke waktu untuk mencerminkan selisih inflasi antar dua negara terbukti tidak berlaku untuk nilai tukar Rupiah terhadap Dollar Amerika Serikat.

Variabel paritas suku bunga berdasarkan rasio suku bunga nominal antara Indonesia dan Amerika Serikat tidak perpengaruh terhadap nilai tukar Rupiah/Dollar Amerika Serikat selama periode penelitian, sehingga teori paritas suku bunga (IRP) yang menyatakan bahwa nilai tukar ditentukan dari perbedaan tingkat suku bunga antar dua negara terbukti tidak berlaku untuk nilai tukar Rupiah terhadap Dollar Amerika Serikat.

Variabel efek fisher internasional berdasarkan rasio suku bunga riil antara Indonesia dan Amerika Serikat terbukti tidak berpengaruh terhadap nilai tukar Rupiah/Dollar Amerika Serikat selama periode pengamatan, sehingga teori efek fisher internasional (IFE) yang menyatakan bahwa nilai tukar ditentukan dari perbedaan tingkat suku bunga riil antara dua negara terbukti tidak berlaku untuk nilai tukar Rupiah terhadap Dollar Amerika Serikat.

\section{DAFTAR PUSTAKA}

Al-Qur'an al-Karim dan terjemahan.

Amalia, Lia. 2007. Ekonomi Internasional. Yogyakarta: Graha Ilmu.

Anggraeni, Dwi. 2007. Pengaruh Model Paritas Daya Beli dan Model Efek

Fisher terhadap Nilai Tukar Rupiah. Skripsi (tidak dipublikasikan). Fakultas Ekonomi Universitas Negeri Malang.

Apriliyani, Ayu Fitri. 2015. Pengujian Empiris Teori International Fisher Effect terhadap Nilai Tukar pada Hubungan Ekonomi Indonesia- 
Jepang. Skripsi (tidak dipublikasikan). Fakultas Ekonomi Universitas Jember.

Boediono. 2008. Teori Pertumbuhan Ekonomi. Yogyakarta: BPFE.

Boone, Louis E., Kurtz, David L. 2007. Pengantar Bisnis Kontemporer Terjemahan Edisi Kesebelas Buku 1. Jakarta: Salemba Empat.

Darmawi, Herman. 2006. Pasar Finansial dan Lembaga-lembaga Finansial. Jakarta: Bumi Aksara.

Eiteman, David K., Stonehill, Arthur I., Moffett, Michael H. 2010. Manajemen Keuangan Multinasional. Terjemahan Edisi Kesebelas. Jakarta: Erlangga.

Eun, Cheol S., Resnick, Bruce G., Sabherwal, Sanjiv. 2013. Keuangan Internasional Edisi Keenam Buku 1. Jakarta: Salemba Empat.

Ghozali, Imam. 2006. Aplikasi Analisis Multivariate dengan SPSS, Edisi Keempat. Semarang: Universitas Diponegoro.

Gujarati, Damodar N., Porter, Dawn C. 2010. Dasar-dasar Ekonometrika Edisi Kelima Buku 1 Terjemahan. Jakarta: Salemba Empat.

Hady, Hamdi. 2010. Manajemen keuangan Internasional Edisi 2. Jakarta: Mitra Wacana Media.

Hanafi, Mamduh. 2003. Manajemen Keuangan Internasional. Yogyakarta: BPFE.

Hasan, Ahmad. (2005). Mata Uang Islami. Jakarta: PT. Grafindo Persada.

Huda, Nurul., Idris, Handi Risza, dkk. 2008. Ekonomi Makro Islam: Pendekatan Teoritis. Jakarta: Kencana.

Joesoef, Jose Rizal. 2008. Pasar Uang dan Pasar Valuta Asing. Jakarta: Salemba Empat.

Karim, Adiwarman A. 2007. Ekonomi Mikro Islam. Jakarta:PT Raja Grafindo.

Krugman, Paul L., Maurice, Obstfeld. 2005. Ekonomi Internasional Edisi Kelima Terjemahan. Jakarta: PT Indeks.

Kuncoro, Mudrajad. 2001. Manajemen Keuangan Internasional: Pengantar Ekonomi dan Bisnis Global Edisi Kedua, Yogyakarta: BPFE.

Lubis, M. Roza Aulia. 2007. Analisis Pengujian Penerapan Purchasing Power Parity pada Mata Uang Rupiah terhadap Dollar Amerika. Tesis (tidak dipublikasikan). Sekolah Pascasarjana Universitas Sumatera Utara.

Madura, Jeff. 2000. Manajemen Keuangan Internasional. Jakarta: Erlangga. 
. 2006. Keuangan Perusahaan Internasional Edisi

Kedelapan Buku 1. Jakarta: Salemba Empat.

Mankiw, N.Gregory. 2003. Teori Makroekonomi Edisi Kelima. Jakrta: Erlangga.

Mankiw, N.Gregory. 2007. Pengantar Ekonomi Makro Edisi Ketiga. Jakarta: Salemba Empat.

Mishkin, Frederre S. 2008). Ekonomi, Uang, Perbankan dan Pasar Keuangan Edisi Kedelapan Buku 2. Jakarta: Salemba Empat.

Murni, Asfia. 2006. Ekonomi Makro. Bandung: PT Refika Aditama.

Nachrowi, Djalal., Usman, Hardius. 2008. Penggunaan Teknik Ekonometri. Jakarta: PT Raja Grafindo Persada.

Nopirin. 1999. Ekonomi Moneter Buku 2. Yogyakarta: BPFE.

Putong, Iskandar. 2007. Pengantar Mikro dan Makro. Jakarta: Mitra Wacana Media.

Rahardja, Prathama., Manurung, Mandala. 2004. Teori Ekonomi Makro Edisi Keempat. Jakarta: Lembaga Penerbit FE UI.

Salim, Joko. 2008. Mengikuti Jejak Bisnis Menggiurkan Orang Tionghoa. Jakarta: Visimedia.

Samuelson, Paul A. 2004. Ilmu Makro Ekonomi. Jakarta: Erlangga.

Santosa, Purbayu Budi., Hamdani, Muliawan. 2007. Statistika Deskriptif dalam Bidang Ekonomi dan Niaga. Jakarta: Erlangga.

Setiawan., Kursrini, Dwi Endah. 2010. Ekonometrika. Yogyakarta: CV Andi Offset.

Sugiyono. 2008. Metode Penelitian Bisnis. Bandung: Alfabeta.

Sukirno, Sadono. 2000. Makro Ekonomi Modern Perkembangan Pemikiran dari Klasik Hingga Keynesian Baru. Jakarta: PT. Raja Grafindo Persada.

Sunariyah. 2006. Pengantar Pengetahuan Pasar Modal, Edisi Kelima. Yogyakarta: UUP APM YKPN.

Syech, Haifa Binti. 2005. Analisa Penentuan Nilai Tukar Rupiah terhadap Dollar Amerika Serikat (Studi Perbandingan antara Paritas Daya Beli dan Paritas Suku Bunga). Skripsi (tidak dipublikasikan). Fakultas Ekonomi Universitas Muhammadiyah Malang.

Trenggonowati. 2009. Metodologi Penelitian Ekonomi dan Bisnis Edisi Pertama. Yogyakarta: BPFE. 
Widyaningsih. 2005. Bank dan Asuransi Islam di Indonesia. Jakarta: Kencana.

Yuliati, Handaru., Prasetyo, Handoyo. 2005. Dasar-dasar Manajemen Keuangan Internasional Edisi Kedua. Yogyakarta: ANDI. 